\title{
The Solution Interaction of Tetrathionate Ions and Sodium Isobutyl Xanthate and Its Effect on the Flotation of Galena and Chalcopyrite
}

\author{
Ngoni Mhonde ${ }^{1, *(\mathbb{D})}$, Leena Pitkänen ${ }^{1}$, Kirsten Corin ${ }^{2}(\mathbb{D})$ and Nóra Schreithofer ${ }^{1}$ \\ 1 Department of Bioproducts and Biosystems, School of Chemical Engineering, Aalto University, \\ 02150 Espoo, Finland; leena.pitkanen@aalto.fi (L.P.); nora.schreithofer@aalto.fi (N.S.) \\ 2 Centre for Minerals Research, Chemical Engineering Department, University of Cape Town, Rondebosch, \\ Cape Town 7701, South Africa; kirsten.corin@uct.ac.za \\ * Correspondence: ngoni.mhonde@aalto.fi
}

Citation: Mhonde, N.; Pitkänen, L.; Corin, K.; Schreithofer, N. The Solution Interaction of Tetrathionate Ions and Sodium Isobutyl Xanthate and Its Effect on the Flotation of Galena and Chalcopyrite. Minerals 2021, 11, 204. https://doi.org/ $10.3390 / \min 11020204$

Academic Editor: Saeed Farrokhpay Received: 25 January 2021

Accepted: 10 February 2021

Published: 15 February 2021

Publisher's Note: MDPI stays neutral with regard to jurisdictional claims in published maps and institutional affiliations.

Copyright: (c) 2021 by the authors. Licensee MDPI, Basel, Switzerland. This article is an open access article distributed under the terms and conditions of the Creative Commons Attribution (CC BY) license (https:// creativecommons.org/licenses/by/ $4.0 /)$.

\begin{abstract}
Tetrathionates have been found in significantly high concentrations in recycled process waters from massive sulphide ore processing plants. These polythionates react with xanthate added to flotation pulps thus reducing xanthate dosages in solution potentially affecting flotation performance. The current study focused on the effect of the tetrathionate-xanthate reaction on sulphide mineral recoveries. Ore dissolution studies confirmed the generation of tetrathionates by copper-lead-zinc ores. In $20 \mathrm{~min}$, the tetrathionates consumed more than half of the xanthate in solution at $\mathrm{pH}$ 7. Rest potential measurements and Fourier transform infrared spectroscopy (FTIR) showed that the degree of collector-mineral interactions of xanthate and both galena and chalcopyrite was greatly reduced in the presence of a $2000 \mathrm{mg} / \mathrm{L}$ tetrathionate solution. Microflotation tests showed that chalcopyrite recovery was less sensitive to tetrathionates as indicated by small changes in mineral recoveries. Galena was sensitive to the action of tetrathionates on the mineral surface as the galena recovery significantly declined when floated with xanthate as a collector in both a $500 \mathrm{mg} / \mathrm{L}$ tetrathionate solution and a $2000 \mathrm{mg} / \mathrm{L}$ tetrathionate solution. These fundamental results lay a sound base on which more discussion into the significance and the effect of tetrathionates on flotation performance of sulphide ores can be developed.
\end{abstract}

Keywords: kinetics; decomposition; adsorption; tetrathionates; xanthyl thiosulphate; ore dissolution; depression

\section{Introduction}

The oxidation and dissolution of sulphide ores in flotation process water leads to the formation of thiosalts. Thiosalts are intermediate sulphur oxidation products namely $\mathrm{S}_{2} \mathrm{O}_{3}{ }^{2-}$ (thiosulphates), $\mathrm{S}_{4} \mathrm{O}_{6}{ }^{2-}$ (tetrathionates), $\mathrm{S}_{3} \mathrm{O}_{6}{ }^{2-}$ (trithionates), and $\mathrm{S}_{5} \mathrm{O}_{6}{ }^{2-}$ (pentathionates), where the three latter compounds are collectively known as polythionates. The production of these polythionates has been described as a catalytic oxidation of thiosulphate primarily by pyrite (and other sulphide minerals) in the presence of oxygen [1-3]. Microorganisms also contribute to the formation of thiosalts from pyrite under the right conditions. The microbial oxidation of pyrite produces thiosulphates as the initial decomposition product, which upon further exposure to microbial oxidation, decomposes to sulphates $\left(\mathrm{SO}_{4}{ }^{2-}\right)$ with $\mathrm{S}_{4} \mathrm{O}_{6}{ }^{2-}$ as a secondary by-product [4-6]. In alkaline conditions, the proposed mechanism involves the alteration of the elemental sulphur inherently oxidising thiosulphate ions to tetrathionate then sulphates [7]. The thermodynamically favoured end product of sulphide oxidation is sulphate, however, in plant process water and plant water effluents, mass transfer and kinetics limitations result in the production of partially oxidised thiosalts or polythionates [8].

The generation of thiosalts is largely a function of operating conditions. These conditions include $\mathrm{pH}$, temperature, grinding time and size, sulphur content, and unit location 
within the mineral beneficiation circuit [8-10]. In flotation pulps, increasing the $\mathrm{pH}$ from neutral to slightly alkaline conditions increases the rate of thiosalts generation and the overall production of thiosalts. High temperatures in the flotation pulps of sulphide ores and increased pulp dilution also result in increased thiosalt concentrations $[8,10]$.

Massive sulphide ores, such as those processed in the New Brunswick region in Canada and at a polymetallic sulphide minerals processing operation in Portugal, exhibit the propensity to produce high amounts of thiosalts. Moreover, ores from stockpiles already possess a high amount of thiosalts on the mineral surface before mixing with process water [9]. Elemental sulphur is the primary oxidation product of the ores exposed to atmospheric air, and it may be a precursor to thiosalts generation $[9,10]$.

Of interest is the phenomenon that although galena and pyrrhotite oxidise relatively faster [11], pyrite seems to generate a majority of thiosalts during processing in the grinding stage $[8,9]$.

Owing to their abundance in flotation plant process waters, thiosulphates ions and tetrathionate ions are of interest to mineral processing researchers. More so, the increased emphasis on plant water recycling at mining sites, closing water loops and short circuit recycling of process water, has led to the accumulation of thiosalts in the flotation circuits. As a result, the existence of partially oxidised sulphur intermediates in plant process waters can no longer be ignored. Much work has considered the behaviour of thiosulphate ions in flotation operations [12-15]. However, less focus has been channelled towards the behaviour of the tetrathionate ions in the flotation process, until now.

This paper will discuss the solution interaction of tetrathionates with flotation reagents i.e., collectors and their interactions with economically important sulphide minerals i.e., galena and chalcopyrite. Galena and chalcopyrite are usually floated in bulk in the first stage of a two-stage sphalerite flotation process $[16,17]$. Owing to the rapid oxidation of galena and its inherent sensitivity, the mineral is often affected by pulp conditions which include $\mathrm{Eh}, \mathrm{pH}$, and other soluble species present in pulp slurries [18-21].

The current research improves the understanding of the flotation efficacy of xanthates (as sulphide collectors) in water with high tetrathionate ion loads e.g., recycled process waters. In addition to elucidating the reaction kinetics of the sodium isobutyl xanthate (SIBX) and tetrathionate reaction, surface interactions of tetrathionates and SIBX on sulphide minerals are investigated. Electrochemistry i.e., rest potential measurements is also considered as the degree of collector-mineral interactions can be analysed in this manner.

\section{Materials and Methods}

2.1. Materials

\subsubsection{Mineral Sample Preparation}

Galena and chalcopyrite used in this study were obtained in chunks from Ward's Science (Rochester, NY, USA). The purity of the samples was assessed using XRD and the results are presented in Table 1. The XRD results table shows that the minerals were of a high grade. Chalcopyrite was $94.3 \%$ pure with chlorite and magnetite making up the bulk $(5.2 \%)$ of remaining mineral impurities. Galena was $98 \%$ pure. To attain fine-sized particles, the chunks were hammered down then pulverised for $20 \mathrm{~s}$. The pulverised powder was sieved to obtain three size fractions i.e., $-25 \mu \mathrm{m},+25-38 \mu \mathrm{m}$, and $+38-108 \mu \mathrm{m}$. The samples were split into representative $2 \mathrm{~g}$ portions. The mineral samples were packed in bottles and purged with nitrogen before storage in the freezer at $-17^{\circ} \mathrm{C}$. The $-25 \mu \mathrm{m}$ size fraction was used in FTIR and XPS studies, the $+38-108 \mu \mathrm{m}$ fraction was employed in microflotation tests, whilst the $+25-38 \mu \mathrm{m}$ fraction was stored in the freezer. 
Table 1. XRD analysis of the mineral samples used in adsorption tests.

\begin{tabular}{ccc}
\hline Sample & Mineral Phases & Purity (\%) \\
\hline \multirow{3}{*}{ Galena } & Galena & 98.2 \\
& Quartz & 0.9 \\
& Cerussite & 0.7 \\
& Hydrocerussite & 0.2 \\
\hline \multirow{2}{*}{ Chalcopyrite } & Chalcopyrite & 94.3 \\
& Chlorite & 2.2 \\
& Magnetite & 3 \\
\hline
\end{tabular}

\subsubsection{Reagents}

Modified deionised water was used throughout the study unless otherwise stated. $\mathrm{Na}_{2} \mathrm{~S}_{4} \mathrm{O}_{6}$ from Sigma Aldrich was used to alter the deionised water. SIBX ( $99 \%$ purity) (Senmin, Sasolburg, South Africa) was used as the thiol collector. The collector was prepared as a $1 \%(w / v)$ stock solution from which the desired aliquot of stock solution was drawn and used in the respective experimental tests. A fresh stock solution was prepared before each set of experiments.

For microflotation tests, the dosing strategy was based on the available mineral surface area as calculated from Brunauer-Emmett-Teller (BET) surface areas and the active collector content. The BET surface areas are shown in Table 2. A 50\% pseudo-monolayer coverage dosage was assumed based on previous literature which observed that at this monolayer coverage, there is the direct interaction between the collector molecules and the mineral surface instead of intramolecular interactions between collector molecules [22]. The average cross-sectional area of the thiol collector molecule head was assumed to be around 28.8 A [23]. NaOH (Merck, Germany) and $\mathrm{HCl}$ (37\%) obtained from VWR Chemicals (Darmstadt, Germany) were prepared as required and used as $\mathrm{pH}$ modifiers in all the tests. Bis (2-hydroxyethyl) amino-tris(hydroxymethyl)methane (Bis-Tris) and $\mathrm{Na}_{2} \mathrm{~S}_{2} \mathrm{O}_{3}$ (Sigma Aldrich) were employed in Capillary Electrophoresis analysis.

Table 2. BET surface areas of galena and chalcopyrite.

\begin{tabular}{cc}
\hline Mineral & BET Surface Area $\left(\mathrm{m}^{2} / \mathbf{g}\right)$ \\
\hline Galena & 0.0688 \\
Chalcopyrite & 0.2327 \\
\hline
\end{tabular}

\subsection{SIBX Decomposition Tests}

SIBX solution decomposition tests were studied using a Hach Instruments DR6000 $\mathrm{UV} /$ Vis spectrophotometer (Hach Lange $\mathrm{GmbH}$, Düsseldorf, Germany). The reaction was initiated by adding $50 \mu \mathrm{L}$ of a $1 \%(w / v)$ stock solution of SIBX to $30 \mathrm{~mL}$ of the desired tetrathionate solution concentration and $\mathrm{pH}$. Similar decomposition tests were also conducted in gas purged solutions. In separate tests, oxygen and nitrogen were respectively purged in tetrathionate-solutions for an hour before SIBX was added. The gases were continuously bubbled in the solution during the duration of the experiment. At selected times, aliquots of the reacting solutions were drawn and measured with the spectrophotometer using a quartz glass cuvette. The absorbance of xanthate was recorded at a wavelength of $301 \mathrm{~nm}$. The absorbance peak values were used to calculate the extent of decomposition and residual xanthate in solution. Nonlinear least squares regression curve fitting and Microsoft Excel's solver function were employed for kinetics studies. Nonlinear least squares regression is preferred as it avoids skewing owing to mathematical manipulation of raw data [24].

\subsection{Ore Dissolution and SIBX Decomposition Tests}

As a validation step to show the generation of polythionates in the flotation circuit and their effect on reagent consumption, an ore dissolution experiment was conducted 
using a polymetallic $\mathrm{Cu}-\mathrm{Pb}-\mathrm{Zn}$ ore obtained from a polymetallic sulphide ore processing mine in Portugal. A detailed description of the dissolution loop strategy and its importance to mineral processing has been described by Le et al. [25]. A $1 \mathrm{~kg}$ sample of ore was ground to $80 \%$ passing $45 \mu \mathrm{m}$ at a solid pulp density of $67 \%$ in a stainless-steel ball mill. The milled slurry was transferred to a $2 \mathrm{~L}$ batch flotation cell and makeup water was added to the cell to achieve the required slurry level ( $35 \%$ slurry density). The slurry was aerated without froth collection and addition of reagents for $50 \mathrm{~min}$. After aeration was completed, the slurry was filtered, and the solids were discarded whilst the water was recycled for milling a fresh ore. The tests were conducted at $25^{\circ} \mathrm{C}$ and $60^{\circ} \mathrm{C}$. The high temperature was achieved by using a thermostatic heating element. After 6 loops of grinding and aeration, $30 \mathrm{~mL}$ of the sample was drawn and vacuum filtered using $1.6 \mu \mathrm{m}$ filter paper followed by filtration using a $0.45 \mu \mathrm{m}$ filter paper. SIBX was added to the filtered water sample and xanthate decomposition was monitored over $1 \mathrm{~h}$. Two extra samples were collected and filtered: (i) was used as a baseline in UV analysis and (ii) was quantitatively analyzed for polythionates using the capillary electrophoresis machine.

\subsection{Capillary Electrophoresis}

The separation and quantitation of tetrathionates and thiosulphates were conducted using the Agilent 7100 Capillary Electrophoresis (CE) equipment (Agilent Technologies, Santa Clara, CA, USA). This robust technique entails the separation of the analytes in an electrolyte medium employing an electric field and spectrometry (UV) [26]. A method developed by O'Reilly [27] was applied with some modifications to suit the in-house unit. An uncoated fused silica capillary tubing (50 $\mu \mathrm{m}$ internal diameter and $375 \mu \mathrm{m}$ outer diameter) with a total length of $0.385 \mathrm{~m}$ was used for the separation of electrolytes. The data was collected using two wavelengths: 195 and $214 \mathrm{~nm}$ with $50 \mathrm{mM}$ Tris-Bis, $\mathrm{pH} 6$ used as a background electrolyte (BGE). A voltage of $-30 \mathrm{kV}$ was used in the separations. Before analysis, the silica capillary was flushed with $1 \mathrm{M} \mathrm{NaOH}$ for $10 \mathrm{~min}$, Milli-Q water for 10 $\mathrm{min}$, and the BGE for $10 \mathrm{~min}$. During analysis, Milli-Q water was injected at $30 \mathrm{mbar}$ for $3 \mathrm{~s}$ just before the sample injection to concentrate the sample by field amplified sample stacking. Liquid samples were then injected using a pressure of $50 \mathrm{mbar}$ with the injection time set at $10 \mathrm{~s}$. Where multiple samples were analysed, shorter $1 \mathrm{~min}$ washing steps were conducted in between successive injections to clean the capillaries. Above $\mathrm{pH} 9$, tetrathionates are unstable in solution, hence, fresh standards were always prepared immediately before the $\mathrm{CE}$ analysis using sodium tetrathionate $\left(\mathrm{Na}_{2} \mathrm{~S}_{4} \mathrm{O}_{6} \cdot 2 \mathrm{H}_{2} \mathrm{O}\right)$.

\subsection{FTIR Measurements}

FTIR measurements were conducted with the aid of a Perkin Elmer-Two Spectrum (FTIR-ATR) spectrometer (Perkin Elmer Inc, Waltham, MA, USA). The equipment is fitted with a $\mathrm{LiTaO}_{3}$ (lithium tantalate) detector and $\mathrm{KBr}$ detection windows for data collection from 350 to $8000 \mathrm{~cm}^{-1}$. Infrared (IR) readings of species on the mineral surface were collected after 32 scans. Before IR readings were taken, $1 \mathrm{~g}$ of mineral sample was conditioned in a solution of deionised water with $5 \times 10^{-4} \mathrm{M}$ SIBX or a $500 \mathrm{mg} / \mathrm{L}$ tetrathionate solution with $5 \times 10^{-4} \mathrm{M} \mathrm{SIBX}$ at the desired $\mathrm{pH}$. The mixture was conditioned for $30 \mathrm{~min}$ before filtration. A freshly conditioned mineral sample was filtered and washed with water and acetone to remove any residual solution before being placed on the crystal. The same filter paper used in microflotation tests was used in this stage of experiments. The mineral sample was pressed down on the Attenuated Total Reflection (ATR) crystal to allow enough contact for reliable IR data readings.

\subsection{Rest Potential Measurements}

Rest potential measurements were carried out under three experimental conditions: in the presence xanthate and tetraborate buffer ( $\mathrm{pH} 9)$; in the presence of tetraborate buffer + xanthate $+500 \mathrm{mg} / \mathrm{L}$ tetrathionate ions and in the presence of tetraborate buffer + xanthate $+2000 \mathrm{mg} / \mathrm{L}$ tetrathionate. Galena and chalcopyrite electrodes were used as test minerals. 
A detailed description of the mineral electrode construction is available in Tadie et al. [28]. A three-electrode electrochemical cell was set up with potentials measured relative to the $\mathrm{Ag} / \mathrm{AgCl}$ and reported against a platinum standard hydrogen electrode (SHE). Before rest potential measurements, the mineral was first polished using a 600 grit silicon carbide paper, followed by finer polishing using alumina powders from IMP Scientific and Precision (Pty) Ltd., (Boksburg, South Africa). Rest potentials were controlled and measured under the desired conditions using a Gamry 3000 Potentiostat (Gamry Instruments Inc, Warminster, PA, USA) and Gamry Framework computer software. Rest potentials were measured in the absence of reagents for 600 and $1500 \mathrm{~s}$ for galena and chalcopyrite, respectively, allowing the surface to equilibrate, followed by SIBX addition at $2.4 \times 10^{-4} \mathrm{M}$.

\subsection{Microflotation Tests}

Microflotation tests were performed using the University of Cape Town microflotation rig. A detailed description of the rig design is provided elsewhere [29]. First, $50 \mathrm{~mL}$ of deionised water or tetrathionate solution at $\mathrm{pH} 8-9$ was added to $2 \mathrm{~g}$ of a previously weighed mineral sample and the mixture was sonicated for $5 \mathrm{~min}$ to remove agglomerates. Post sonication, the desired concentration of SIBX required for a $50 \%$ monolayer coverage of the mineral surface was added to the mixture followed by conditioning for $3 \mathrm{~min}$. If necessary, the $\mathrm{pH}$ was adjusted using $\mathrm{NaOH}$ and $\mathrm{HCl}$. The mixture was transferred to the microflotation cell. Tetrathionate concentrations of 500 and $2000 \mathrm{mg} / \mathrm{L}$ were tested based on previous water quality survey results from a polymetallic sulphide ore processing plant, Portugal (confidential reports) (see Table 3). Makeup deionised water or tetrathionate solution when appropriated was added to the cell to reach the recommended water level mark. Air was introduced into the cell at a flow rate of $8 \mathrm{~L} / \mathrm{min}$ using a peristaltic pump attached to a needle injector. Concentrates were collected from the top of the cell at 2, 6, 12, and $20 \mathrm{~min}$ of flotation. The concentrates were filtered using an MN615 grade cellulose filter paper (Macherey-Nagel- Duren, Germany) with a thickness of $0.16 \mathrm{~mm}$ and a pore size of 4-12 $\mu \mathrm{m}$. After filtration, the solids were dried in the oven at $70^{\circ} \mathrm{C}$ before weighing. A mass balance between the tails and concentrates was used to calculate the recoveries.

Table 3. Chemical species and their concentration ranges in plant waters at a polymetallic sulphide ore processing operation in Portugal (Site survey reports).

\begin{tabular}{ccc}
\hline Species & Concentration Range & Units \\
\hline $\mathrm{S}_{4} \mathrm{O}_{6}{ }^{2-}$ & $200-2500$ & $\mathrm{mg} / \mathrm{L}$ \\
$\mathrm{S}_{2} \mathrm{O}_{3}{ }^{2-}$ & $5-900$ & $\mathrm{mg} / \mathrm{L}$ \\
$\mathrm{SO}_{4}{ }^{2-}$ & $300-4000$ & $\mathrm{mg} / \mathrm{L}$ \\
$\mathrm{Ca}^{2+}$ & $2-900$ & $\mathrm{mg} / \mathrm{L}$ \\
Dissolved Oxygen Content & $6-11$ & $\mathrm{ppm}$ \\
$\mathrm{TOC}_{\mathrm{Cl}^{-}}$ & $5-13$ & $\mathrm{mg} / \mathrm{L}$ \\
$\mathrm{NO}^{3-}$ & $100-3600$ & $\mathrm{mg} / \mathrm{L}$ \\
$\mathrm{Pb}^{2+}$ & $5-100$ & $\mathrm{mg} / \mathrm{L}$ \\
$\mathrm{Na}^{+}$ & $0.01-20$ & $\mathrm{mg} / \mathrm{L}$ \\
$\mathrm{Mg}^{2+}$ & $5-1100$ & $\mathrm{mg} / \mathrm{L}$ \\
$\mathrm{K}^{+}$ & $0.1-300$ & $\mathrm{mg} / \mathrm{L}$ \\
$\mathrm{pH}$ & $2-120$ & $\mathrm{mg} / \mathrm{L}$ \\
\hline
\end{tabular}

\section{Results}

\subsection{Xanthate Degradation Kinetics in the Presence of Tetrathionates}

Previous studies have shown that no appreciable xanthate decomposition occurs in deionised water at neutral to alkaline $\mathrm{pH}$ i.e., in the absence of sulphoxy compounds. These results are confirmed and published in [30,31]. In the current study, the concentration of SIBX in tetrathionate solutions was normalised by the initial SIBX concentration. Residual xanthate concentrations in the presence of tetrathionate solutions were measured over $1 \mathrm{~h}$ at $\mathrm{pH} 3,5,7,9$ and 11 . As shown in Figure 1, at least $50 \%$ of the xanthate is consumed in the 
first $10 \mathrm{~min}$ of exposure to tetrathionate ions. After $1 \mathrm{~h}$, all the xanthate is almost completely degraded at all $\mathrm{pH}$ conditions investigated. Investigations into the use of oxygen and nitrogen, Figure 2, showed no statistically significant results from those presented in Figure 1 (refer to Supplementary Materials Tables S1-S3 for the two-way ANOVA results). The results, therefore, suggested that the reaction was not affected by the nature of gas in the solution and no further investigation into gases was considered.

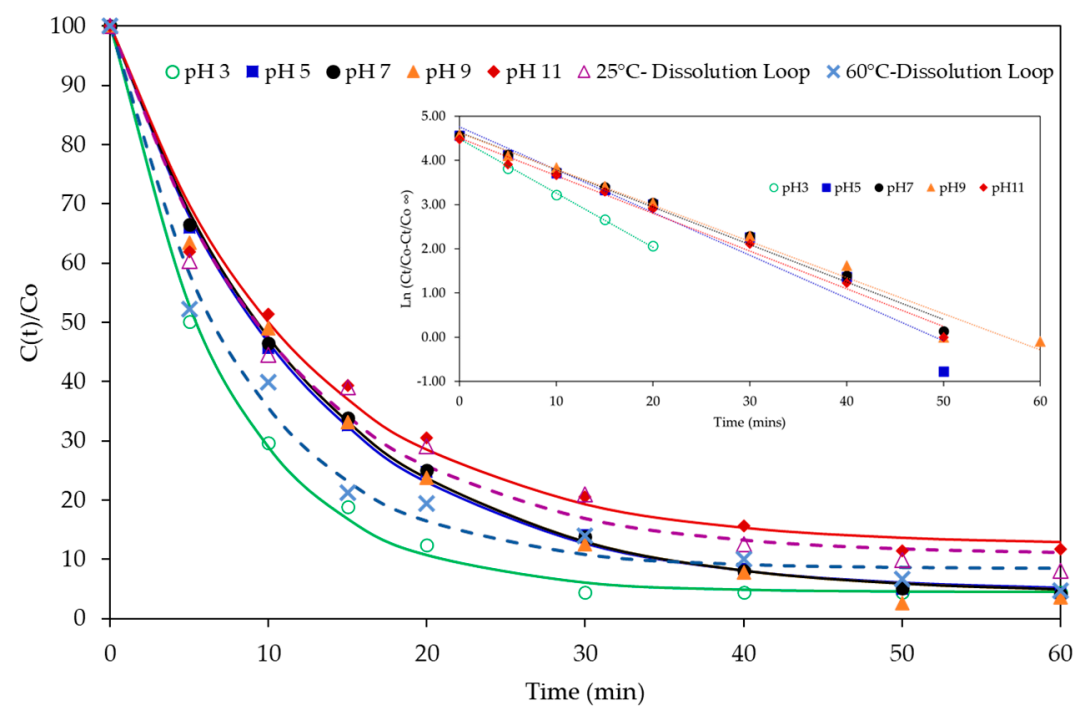

Figure 1. Normalised residual xanthate in solution after decomposition in $500 \mathrm{mg} / \mathrm{L}$ tetrathionates solution at $\mathrm{pH} 3,5,7,9,11$ and dissolution loop water. Starting SIBX solution $=20 \mathrm{mg} / \mathrm{L}$. (Inset: Linearised natural logarithm of normalised concentration vs. time).
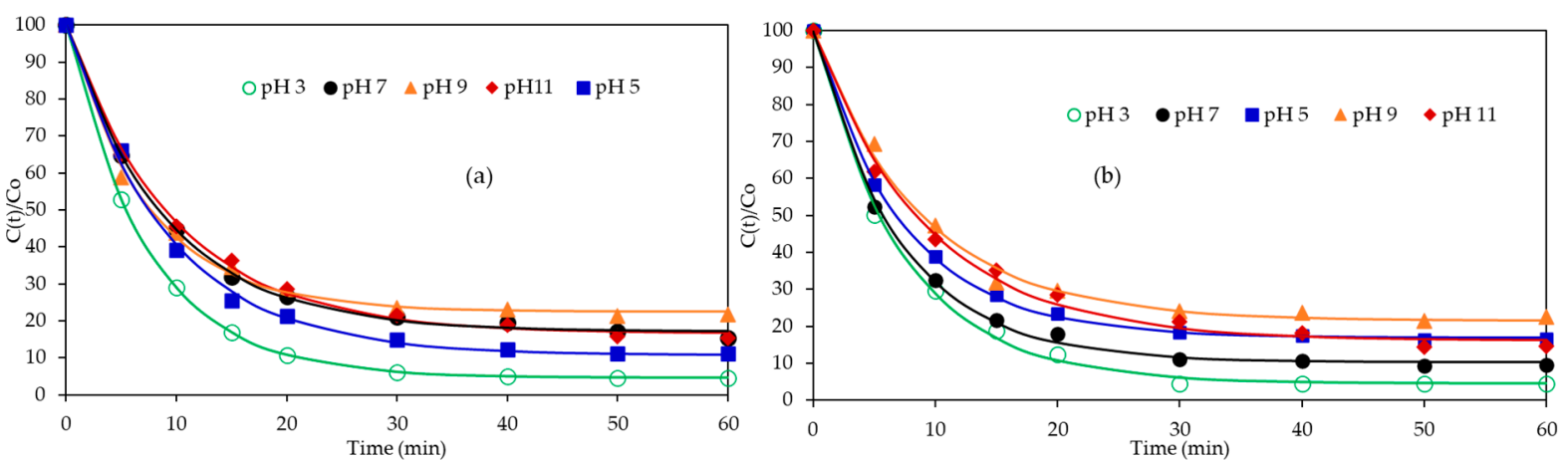

Figure 2. SIBX decomposition in the presence of (a) oxygen and (b) nitrogen purging. SIBX starting concentration $=20 \mathrm{mg} / \mathrm{L}$.

The reaction kinetics of the tetrathionate and SIBX system were evaluated using regression fitting. Equations (1) and (2) show the nonlinear and linearised equations respectively used to analyze the reaction progress. $(\mathrm{Ct} / \mathrm{Co})$ represents the normalised residual concentration at any time $\mathrm{t},(\mathrm{Ct} / \mathrm{Co})_{\infty}$ is the normalised residual concentration at an infinite time and $\mathrm{k}$ is the rate constant:

$$
\begin{gathered}
\left(C_{t} / C_{o}\right)-\left(C_{t} / C_{o}\right)_{\infty}=\left[\left(C_{t} / C_{o}\right)_{\text {initial }}-\left(C_{t} / C_{o}\right)_{\infty}\right] . e^{-k t}, \\
\operatorname{Ln}\left[\left(C_{t} / C_{o}\right)-\left(C_{t} / C_{o}\right)_{\infty}\right]=\operatorname{Ln}\left[\left(C_{t} / C_{o}\right)_{\text {initial }}-\left(C_{t} / C_{o}\right)_{\infty}\right]-k t .
\end{gathered}
$$

The reaction is first order with respect to the xanthate in solution. The dependence of the natural logarithm of residual xanthate concentration on time is also shown in the inset in Figure 1. The inset shows a linear relationship between the natural logarithm of normalised xanthate concentration and time, supporting the nonlinear curve fitting results. 
Rate constants for the data presented from curve fitting are also presented in Table 4 . The fastest SIBX decomposition rate in all solutions is observed at $\mathrm{pH} 3$ with a rate constant (k) of $0.136 \mathrm{~min}^{-1}$ in the $500 \mathrm{mg} / \mathrm{L}$ tetrathionate solution. This is expected as xanthates are unstable in highly acidic conditions. Therefore, the impact of tetrathionates on SIBX decomposition was considered for $\mathrm{pH}$ values above $\mathrm{pH}$ 5. Beyond $\mathrm{pH} 5$, decomposition rates are almost the same. This result suggests that above $\mathrm{pH} 5, \mathrm{pH}$ had no significant bearing on the decomposition rate. As can be seen from Table 4, SIBX decomposition rate constants double as the concentration of tetrathionates doubles which is expected for first-order reaction.

Table 4. Removal ratio of SIBX and related rate constants after $1 \mathrm{~h}$ of conditioning at $\mathrm{pH} 3-11$.

\begin{tabular}{|c|c|c|c|c|c|c|}
\hline $\mathrm{S}_{4} \mathrm{O}_{6}{ }^{2-}$ Concentration & - & & & Solution $\mathrm{pH}$ & & \\
\hline & & 3 & 5 & 7 & 9 & 11 \\
\hline $500 \mathrm{mg} / \mathrm{L}$ & $\begin{array}{l}\text { Rate }(\mathrm{k}) \min ^{-1} \\
\% \text { removal SIBX }\end{array}$ & $\begin{array}{c}1.36 \times 10^{-1} \\
98\end{array}$ & $\begin{array}{c}8.20 \times 10^{-2} \\
97\end{array}$ & $\begin{array}{c}7.94 \times 10^{-2} \\
96\end{array}$ & $\begin{array}{c}7.86 \times 10^{-2} \\
96\end{array}$ & $\begin{array}{c}8.45 \times 10^{-2} \\
88\end{array}$ \\
\hline $250 \mathrm{mg} / \mathrm{L}$ & $\begin{array}{l}\text { Rate }(\mathrm{k}) \min ^{-1} \\
\% \text { removal SIBX }\end{array}$ & $\begin{array}{c}1.25 \times 10^{-1} \\
97\end{array}$ & $\begin{array}{c}5.27 \times 10^{-2} \\
91\end{array}$ & $\begin{array}{c}4.45 \times 10^{-2} \\
90\end{array}$ & $\begin{array}{c}4.11 \times 10^{-2} \\
91\end{array}$ & $\begin{array}{c}4.49 \times 10^{-2} \\
78\end{array}$ \\
\hline $100 \mathrm{mg} / \mathrm{L}$ & $\begin{array}{l}\text { Rate }(\mathrm{k}) \mathrm{min}^{-1} \\
\% \text { removal SIBX }\end{array}$ & $\begin{array}{c}1.32 \times 10^{-1} \\
97\end{array}$ & $\begin{array}{c}2.49 \times 10^{-2} \\
62\end{array}$ & $\begin{array}{c}2.87 \times 10^{-2} \\
61\end{array}$ & $\begin{array}{c}1.94 \times 10^{-2} \\
59\end{array}$ & $\begin{array}{c}2.45 \times 10^{-2} \\
35\end{array}$ \\
\hline
\end{tabular}

As validation of SIBX consumption in process waters, SIBX decomposition was monitored in water loaded with polythionates generated naturally in a real ore dissolution loop. The decomposition of SIBX in dissolution loop water over $1 \mathrm{~h}$ at two temperatures i.e., $25^{\circ} \mathrm{C}$ and $60^{\circ} \mathrm{C}$, is also presented in Figure 1. The absolute SIBX decomposition and kinetics follow a similar pattern to decomposition in artificial tetrathionate solutions. The $\mathrm{pH}$ values of the water samples, $\mathrm{pH} 7\left(25^{\circ} \mathrm{C}\right)$ and $\mathrm{pH} 4\left(60^{\circ} \mathrm{C}\right)$, were not adjusted and SIBX decomposition was initiated at this natural $\mathrm{pH}$. An increase in temperature is accompanied by a decrease in pulp $\mathrm{pH}$ corroborating findings made by Le et al. [25] where the dissolution loop was set up for a $\mathrm{Cu}-\mathrm{Ni}$ ore. This observation was attributed to the release of $\mathrm{H}^{+}$ions as the sulphur in elemental sulphur was oxidised to higher oxidation states forming thiosalts and sulphate [9,25]. High temperatures can be generated in ball mills and in processing plants located in hot regions such as Portugal and South Africa where temperatures have been observed to reach $60{ }^{\circ} \mathrm{C}$ in the mill and $40-50{ }^{\circ} \mathrm{C}$ in the pulp. These temperatures potentially introduce processing problems related to collector adsorption efficiency and collector consumption [32].

\subsection{Evaluation of Ore Dissolution and SIBX Decomposition Products in the Presence of Tetrathionates}

\subsubsection{Identification of Xanthate Derivates}

Figure 3 presents the ultraviolet absorption spectra of xanthates in a tetrathionate solution at $\mathrm{pH} 7$. The spectra were collected at selected times during the reaction. The starting concentration of SIBX was $20 \mathrm{mg} / \mathrm{L}$. In the early stages of the reaction i.e., the first $10 \mathrm{~min}$, the absorbance peak is centred around $301 \mathrm{~nm}$. However, as the reaction progresses the peaks shift towards lower wavelengths.

The pattern in Figure 3 is consistent with observations by Yamamoto and Jones and Woodcock [33,34], who reported on peak shifts from $301 \mathrm{~nm}$ towards $295 \mathrm{~nm}$ when assessing xanthate decomposition in the presence of sulphite ions. Misra et al. [35] suggested the shift is controlled by perxanthate (xanthate derivative) in acidic solution. Their studies were, however, conducted at $\mathrm{pH} 4.9$, hence this species may not be present in our system which was at neutral $\mathrm{pH}$. Furthermore, the characteristic peak of perxanthate expected with an absorbance at $347 \mathrm{~nm}$ [33-35], was not observed in our system even at pH 5 and 3. Jones and Woodcock [34] proposed an alkyl xanthyl thiosulphate as the species responsible for the shift in absorbance peaks of xanthate ions. Xanthyl thiosulphates have absorption 
peaks between 285 and $295 \mathrm{~nm}$. It can be inferred that the overall absorption peak observed in the current studies were a combination of the xanthate absorbance at $301 \mathrm{~nm}$ and the alkyl xanthyl thiosulphate absorbance, explaining the peak shift from $301 \mathrm{~nm}$ towards $290 \mathrm{~nm}$ as xanthate degrades. Care was taken to record true xanthate contributions to absorption peaks by lowering the $\mathrm{pH}$ to below $\mathrm{pH} 2$, rapidly degrading xanthate in sample aliquots. By measuring the difference in absorption peak heights before and after xanthate removal, the real residual xanthate in solution according to method 2 developed by Jones and Woodcock [36] was calculated.

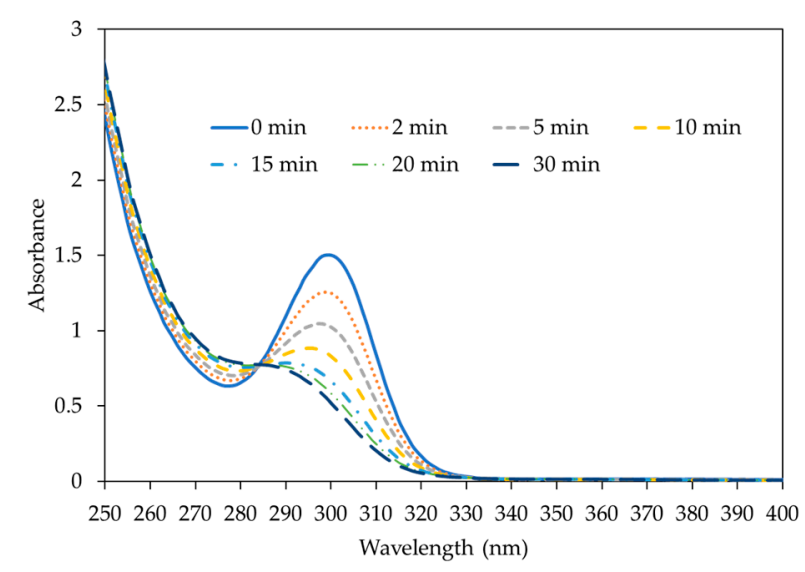

Figure 3. UV spectra of SIBX and its decomposition products in $500 \mathrm{mg} / \mathrm{L}$ of tetrathionates at $\mathrm{pH} 7$.

The oxidation of xanthate ions by tetrathionate ions occurs according to Equation (3) where xanthyl thiosulphates and thiosulphates are reaction products. This reaction favours acidic conditions to alkaline conditions ( $\mathrm{pH} 5-10$ ). Thiosulphates have a detrimental effect on flotation performance of $\mathrm{Cu}-\mathrm{Pb}-\mathrm{Zn}$ ores [37]. Thiosulphate ions inhibit xanthate adsorption on sulphides possibly through competitively adsorbing on the mineral surface and through the formation of complexes with metals leading to mineral passivation [14,15]. In this study, it can be inferred that thiosulphate generation can contribute to surface passivation of the galena and chalcopyrite surface, supporting the lower mineral recoveries observed in the presence of tetrathionate ions.

Simultaneous oxidation of xanthate by tetrathionate ions results in the formation of dixanthogen as in Equation (4) $[12,34,38]$. Although dixanthogen was not detected in the current tests, probably due to low concentrations, dixanthogen is produced via this reaction in conditions where recycled water with high tetrathionate concentrations prevail e.g., plant waters processing massive sulphide ores:

$$
\begin{aligned}
& \mathrm{S}_{4} \mathrm{O}_{6}{ }^{2-}+\mathrm{RX}^{-}=\mathrm{RX} . \mathrm{S}_{2} \mathrm{O}_{3}+\mathrm{S}_{2} \mathrm{O}_{3}{ }^{2-} \\
& \mathrm{S}_{4} \mathrm{O}_{6}{ }^{2-}+2 \mathrm{RX}^{-}=\left(\mathrm{RX}_{2}\right)+2 \mathrm{~S}_{2} \mathrm{O}_{3}{ }^{2-}
\end{aligned}
$$

Jones and Woodcock [34] recognised these interactions, acknowledging the potential interference of tetrathionates with flotation efficacy and highlighting the need for such studies to be conducted. Given that no further studies on this reaction have been explored yet, this paper becomes more pertinent.

\subsubsection{Identification of Thiosalts Using Capillary Electrophoresis}

The electropherograms of tetrathionates and thiosulphates under different reaction conditions for $1 \mathrm{~h}$ are shown in Figure 4 . In all tests, the starting solution consisted of $100 \mathrm{mg} / \mathrm{L}$ of a tetrathionate solution. The migration time of tetrathionates is between 1.8 and $2 \mathrm{~min}$ whilst that of thiosulphates is between 1.3 and $1.4 \mathrm{~min}$. The peak areas were converted to concentrations against calibration curves. After $1 \mathrm{~h}$ of reacting with SIBX, the area under the tetrathionate peak decreases. Concurrently the peaks areas for thiosulphates 
increases with reaction progress. The changes in thiosalt concentrations are reported in Table 5 and support the reaction stoichiometry in Equation (3). As expected, in the presence of $100 \mathrm{mg} / \mathrm{L}$ SIBX, more thiosulphates are produced in comparison to when $60 \mathrm{mg} / \mathrm{L}$ of SIBX was added to the tetrathionate solution. Freestanding $100 \mathrm{mg} / \mathrm{L}$ tetrathionate solution at $\mathrm{pH} 7$ was stable and does not decompose even after $1 \mathrm{~h}$.

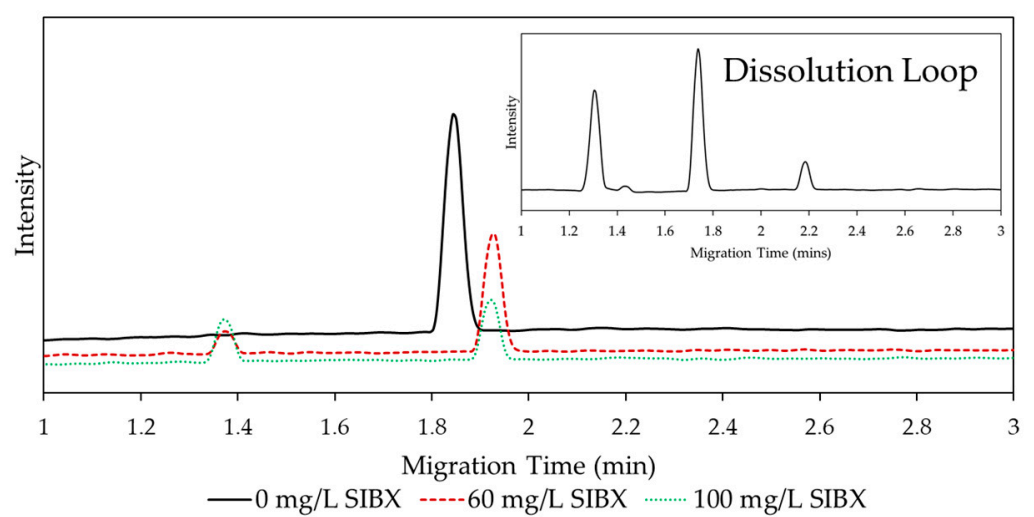

Figure 4. Electropherogram of tetrathionates and thiosulphate ions present after reacting SIBX with tetrathionates for $1 \mathrm{~h} . \mathrm{S}_{4} \mathrm{O}_{6}{ }^{2-}$ starting concentration $=100 \mathrm{mg} / \mathrm{L}$. Inset (top right) shows the electropherogram of water harvested from a dissolution loop in the absence of SIBX.

Table 5. Thiosalt concentration after reacting $100 \mathrm{mg} / \mathrm{L}$ tetrathionates with $60 \mathrm{mg} / \mathrm{L} \mathrm{SIBX}$ and $100 \mathrm{mg} / \mathrm{L}$ SIBX for one hour at $\mathrm{pH} 7$.

\begin{tabular}{ccc}
\hline Sample ID & $\mathbf{S}_{\mathbf{4}} \mathbf{O}_{6}{ }^{2-}$ Concentration $(\mathbf{m g} / \mathbf{L})$ & $\mathbf{S}_{\mathbf{2}} \mathbf{O}_{\mathbf{3}}{ }^{2-}$ Concentration $(\mathbf{m g} / \mathbf{L})$ \\
\hline $\mathrm{S}_{4} \mathrm{O}_{6} 100 \mathrm{mg} / \mathrm{L}$, fresh & 96.89 & 0 \\
$\mathrm{~S}_{4} \mathrm{O}_{6} 100 \mathrm{mg} / \mathrm{L}$, after 1 h & 96.89 & 0 \\
$\mathrm{~S}_{4} \mathrm{O}_{6} 100 \mathrm{mg} / \mathrm{L}+\mathrm{SIBX}$ 60 mg/L, after 1 $\mathrm{h}$ & 50.24 & 46.84 \\
$\mathrm{~S}_{4} \mathrm{O}_{6} 100 \mathrm{mg} / \mathrm{L}+$ SIBX 100 mg/L, after 1 $\mathrm{h}$ & 25.12 & 84.31 \\
\hline
\end{tabular}

The polymetallic sulphide ore mine site survey results summarised in Table 3 confirm the high concentrations of tetrathionate ions and sulphates ions present in process plant waters. The inset in Figure 4 equally shows the naturally occurring thiosalts generated during ore dissolution of a Portuguese polymetallic sulphide ore sample in the absence of reagents. Multiple sulphoxy compound peaks appeared; however, some could not be assigned i.e., at 1.45 and $2.2 \mathrm{~min}$. As noted by Miranda-Trevino [26], the challenge with analytical techniques is their inadequacies in identifying all the species present in complex solutions. For example, challenges arise in the detection of sulphites and sulphates using CE due to little or no UV absorbance in direct CE method prompting the need for indirect techniques [39]. Instrument modifications may be required for the confident assignment of some peaks. What is certain from Figure 4 is the presence of tetrathionates and thiosulphate as indicated by the retention times similar to those exhibited by standard thiosalt reference solutions. A shift of the tetrathionate peak to $1.74 \mathrm{~min}$ is attributed to interference in the more complex solutions. The concentrations of tetrathionates and thiosulphates obtained from the dissolution loop were recorded in addition to sulphate concentrations which were obtained using Hach Instruments sulphate kits. These concentrations are presented in Table 6. 
Table 6. Thiosalt concentrations measured in 'process' water harvested after ore dissolution tests.

\begin{tabular}{ccccc}
\hline Experiment & $\left.\mathbf{S O}_{\mathbf{4}}{ }^{2-} \mathbf{( m g} / \mathrm{L}\right)$ & $\mathbf{S}_{\mathbf{2}} \mathbf{O}_{3}{ }^{2-}(\mathbf{m g} / \mathrm{L})$ & $\mathbf{S}_{\mathbf{4}} \mathbf{O}_{6}{ }^{2-}(\mathbf{m g} / \mathrm{L})$ & Thiosalts $\mathbf{O v e r a l l ~ ( m g / L ) ~}$ \\
\hline Dissolution Loop at $25^{\circ} \mathrm{C}$ & 2034 & 244 & 733 & 1648 \\
Dissolution Loop at $60^{\circ} \mathrm{C}$ & 2056 & 136 & 567 & 1404 \\
\hline
\end{tabular}

As seen in Table 6, tetrathionates are more prevalent in solution in comparison to thiosulphate ions. This result agrees with earlier studies by Goldhaber [40], who observed that in short term experiments lasting less than $48 \mathrm{~h}$, tetrathionates and sulphates are major oxidation intermediates at $\mathrm{pH} 6-7$.

As multiple oxidation-reduction couples exist in the pulp, the overall thiosalts concentration presented in Table 6, is a combination of various other unidentified sulphoxy species plus tetrathionates and thiosulphate ions. There is a decline in thiosalt concentrations as the temperature is raised from 25 to $60^{\circ} \mathrm{C}$. As generally accepted, thiosalt chemistry is complex. Besides reacting with oxygen, the thiosalts also react with each other making the system more difficult to predict $[3,8,26]$. Further oxidation of thiosalts to sulphates and degradation or rearrangement of polythionates to other sulphoxy species is possible. Interestingly the overall thiosalt concentration decreases as the temperature is raised, which is contrary to results presented in previous literature studies $[8,9]$.

Mineralogical analysis of the $\mathrm{Cu}-\mathrm{Pb}-\mathrm{Zn}$ ore shows that the mineralisation is abundant in pyrite, $86 \%$. Being a massive sulphide ore, the pyrite is the major contributor to tetrathionates formation via the formation of thiosulphates as the first oxidation product [3]. In the absence of the pyrite, the reaction between thiosulphate and oxygen is extremely slow [2]. However, due to its semiconducting property [2,8], pyrite acts as a pathway for electron transfer from the thiosulphate (donor) to the oxygen (terminal electron acceptor). As $3 \mathrm{~d}$ electrons fill the conduction band in pyrite, it develops strong metallic properties allowing easy transportation of electrons. From this hypothesis, we can infer that the production of tetrathionates in the presence of galena and sphalerite, also semiconductors, follows the same path. Copper (II) ions have also been reported to catalyze the decomposition of thiosulphate presenting fouling problems of exchange resins in gold processing [1]. The copper released from chalcopyrite oxidative dissolution and reagents such as copper (II) sulphate employed as a sphalerite activator may result in the generation of tetrathionates in solution.

\subsection{Surface Analysis_FTIR Studies}

\subsubsection{Galena FTIR Spectra}

Figure 5a shows the baseline corrected FTIR spectrum of galena conditioned in deionised water without the addition of SIBX. The conditioning was carried out for $30 \mathrm{~min}$ at $\mathrm{pH}$ 7. Galena surfaces are easily oxidised and the sulphoxy oxidised species are present on the mineral surface. From the FTIR spectrum, bands at 837 and $1390 \mathrm{~cm}^{-1}$ originate from $\mathrm{PbCO}_{3}$ whilst the bands appearing at 965 and $1165 \mathrm{~cm}^{-1}$ are indicative of the presence of $\mathrm{PbSO}_{4}$ [41-43]. Conditioning in (i) deionised water (ii) in $500 \mathrm{mg} / \mathrm{L}$ tetrathionates and SIBX $\left(5 \times 10^{-4} \mathrm{M} / 80 \mathrm{mg} / \mathrm{L}\right)$ and (iii) $2000 \mathrm{mg} / \mathrm{L}$ of tetrathionate ions and SIBX (5 × 10 $\left.0^{-4} \mathrm{M} / 80 \mathrm{mg} / \mathrm{L}\right)$, resulted in the FTIR spectra (i), (ii), and (iii), presented in Figure $5 b$.

The concentration of SIBX in solutions used in FTIR tests is higher than what is normally present in process waters, however, to obtain decent infrared spectra, the higher concentration was used. New peaks appear at 1210,1188, 1138, and $1027 \mathrm{~cm}^{-1}$. The peaks at 1210 and $1188 \mathrm{~cm}^{-1}$ are related to C-O-C and S-C-S asymmetric stretching. The band at $1027 \mathrm{~cm}^{-1}$ is attributed to the vibration of the S-C-S group which shifts from 1022 to $1027 \mathrm{~cm}^{-1}$. All these bands correspond to the monocoordinated form of lead butyl xanthate and multiple layers of surface precipitated lead butyl xanthate [42]. The results have no indication of dixanthogen forming on the galena surface. The surface precipitated lead alkyl (ethyl, amyl, butyl) xanthates has been proposed to form on the galena surface according 
to two mechanisms (1) lead salts such as carbonate and sulphate dissolve into solution allowing free $\mathrm{Pb}^{2+}$ ions in solution. In the presence of butyl xanthate ions interactions between the xanthate and $\mathrm{Pb}^{2+}$ allow the formation of lead xanthate. (2) As the solubility limit of the lead alkyl xanthate is surpassed, islands of solid lead alkyl xanthate form on the galena particles acting as nuclei for further precipitation [12,17]. In cases where the galena is highly oxidised, there is a higher probability of precipitates forming, and these have been reported to be enough to induce mineral hydrophobicity when short chain lead ethyl xanthate is employed [43].
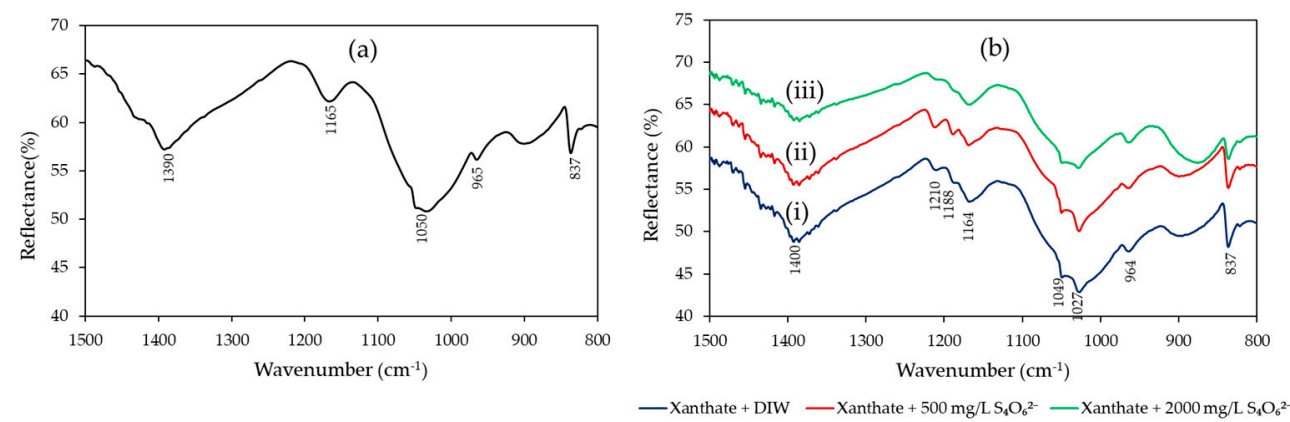

Figure 5. (a) FTIR spectrum of galena before treatments with xanthate; (b) FTIR of spectra of galena conditioned at pH 7 in (i) $\mathrm{DIW}+\left(80 \mathrm{mg} / \mathrm{L} ; 5 \times 10^{-4} \mathrm{M}\right) \mathrm{SIBX}$, (ii) $500 \mathrm{mg} / \mathrm{L}$ tetrathionate solution $+\left(80 \mathrm{mg} / \mathrm{L} ; 5 \times 10^{-4} \mathrm{M}\right) \mathrm{SIBX}$, (iii) $2000 \mathrm{mg} / \mathrm{L}$ tetrathionate solution $+\left(80 \mathrm{mg} / \mathrm{L} ; 5 \times 10^{-4} \mathrm{M}\right)$ SIBX.

After conditioning was carried out in tetrathionate solutions, the intensity of the peaks attributed to lead butyl xanthate decreased as the concentration of tetrathionates increases. This is more evident in spectra (ii) at the high concentration of $2000 \mathrm{mg} / \mathrm{L}$ of tetrathionates. The decrease in peaks could be a result of xanthate consumption in solution or limited adsorption on the mineral surface owing to passivation by metal-thiosalt complexes [37]. This rendered the mineral hydrophilic. At high tetrathionate concentrations, there is also a decrease in intensity of the surface oxidised lead carbonates species bands $\left(837 \mathrm{~cm}^{-1}\right.$ and $1400 \mathrm{~cm}^{-1}$ ) in the presence of tetrathionates. This may be indicative of the propensity of tetrathionates to increase the dissolution of the carbonate species in solution through an ion-exchange mechanism allowing the other sulphoxy ions to form on the galena surface. Minimal changes in the intensity of the sulphate bands $\left(1164 \mathrm{~cm}^{-1}\right.$ and $\left.965 \mathrm{~cm}^{-1}\right)$ even in the presence of the tetrathionates may indicate minimal dissolution of the sulphates from galena in the presence of tetrathionates. This could be explained by contributions to sulphate and thiosulphate species build up on the mineral surface due to oxidation of thiosulphates and tetrathionates, however, the speed of thiosalt oxidation to sulphate is yet to be established.

\subsubsection{Chalcopyrite FTIR Spectra}

Figure $6 \mathrm{a}$ is an illustration of the baseline corrected FTIR spectrum of chalcopyrite conditioned in deionised water in the absence of any collectors. The spectrum contains no peaks, which shows that there is not much oxidation on the chalcopyrite surface. After conditioning in deionised water, spectrum (i) in Figure $6 \mathrm{~b}$ was attained in $5 \times 10^{-4} \mathrm{M}$ SIBX solution.

Two major peaks are identified together with smaller peaks characterised by lower intensities in the regions between 1100 to $1200 \mathrm{~cm}^{-1}$. From comparisons with past findings, the intense peaks at 1027 and $1257 \mathrm{~cm}^{-1}$ are due to the $\mathrm{C}-\mathrm{O}-\mathrm{C}$ asymmetric stretching vibrations and $C=S$ stretching vibrations respectively $[44,45]$. These peaks are attributed to butyl dixanthogen $(\mathrm{BX})_{2}$. The lower intensity peaks identified at 1160,1146,1124, and $1046 \mathrm{~cm}^{-1}$ are attributed to C-O-C symmetric vibrations associated with $(\mathrm{BX})_{2}, \mathrm{C}-\mathrm{O}-\mathrm{C}$ symmetric vibrations associated with cuprous $(\mathrm{I})$ butyl xanthate $(\mathrm{CuBX})$ and $\mathrm{C}=\mathrm{S}$ stretching vibrations linked to $\mathrm{CuBX}[44,46,47]$. From the infrared spectrum, it is quite clear that 
the dominant feature present on the chalcopyrite surface was the adsorbed $(\mathrm{BX})_{2}$ with some xanthate adsorbing as $\mathrm{CuBX}$ in smaller amounts. These results corroborate findings made by Li et al. [47]. Studies by Zhang et al. [44], suggested that cupric(II) butyl xanthate $\left(\mathrm{Cu}(\mathrm{BX})_{2}\right)$ is unstable leading to the dissociation of the cupric butyl xanthate into cuprous(I) butyl xanthate $\mathrm{CuBX}$ and dixanthogen which are more stable on the mineral surface.
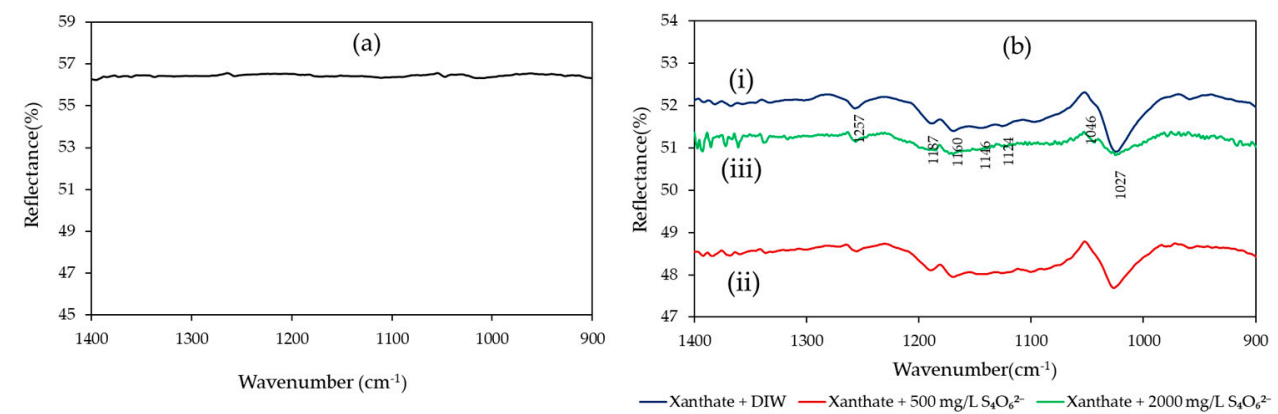

Figure 6. (a) FTIR spectrum of chalcopyrite before conditioning with xanthate; (b) FTIR spectra of chalcopyrite conditioned at $\mathrm{pH} 7$ in (i) Deionised water $+\left(80 \mathrm{mg} / \mathrm{L} ; 5 \times 10^{-4} \mathrm{M}\right) \mathrm{SIBX}$, (ii) $500 \mathrm{mg} / \mathrm{L}$ tetrathionate solution $+\left(80 \mathrm{mg} / \mathrm{L} ; 5 \times 10^{-4} \mathrm{M}\right)$ SIBX, (iii) $2000 \mathrm{mg} / \mathrm{L}$ tetrathionate solution $+\left(80 \mathrm{mg} / \mathrm{L} ; 5 \times 10^{-4} \mathrm{M}\right) \mathrm{SIBX}$.

Conditioning of chalcopyrite in tetrathionate solutions (spectrum (ii) and (iii)), revealed interesting properties of the chalcopyrite surface. At a low tetrathionate concentration i.e., $500 \mathrm{mg} / \mathrm{L}$, there is hardly any change in the FTIR spectrum of chalcopyrite. From this lack of change in the spectrum, it can be inferred that the tetrathionates did not affect xanthate adsorption on to the mineral surface. Possibly the low concentration of thiosulphate produced by the tetrathionate led to reduced mineral passivation by metal-thiosalt complexes. The presence of strong dixanthogen peaks is indicative of the dixanthogen permitting potentials which allow dixanthogen to remain on the surface as will be confirmed by rest potential measurements. At higher tetrathionate concentrations, almost all the peaks produced via the adsorption of sodium butyl xanthate disappear. Of the adsorbed species, $\mathrm{CuBX}$ is the most affected. It can be suggested that increased xanthate solution degradation and competitive adsorption on the mineral surface between the xanthate species and the thiosulphates (or thiosulphate complexes) formed according to Equation (1), resulted in low collector adsorption. The results presented in Section 3.3 indicate that high concentrations of tetrathionates result in decreased interaction between sulphide minerals and alkyl xanthates. To confirm this observation, rest potential measurements were performed.

\subsection{Rest Potential Measurements}

\subsubsection{Galena Rest Potential Measurements}

Figure 7 presents the rest potential (mixed potential) measurements of galena electrodes in different tetrathionate solutions. At all tested conditions, there is a drop in mixed potential after SIBX is added. The extent of the drop in mixed potential and the associated gradient after collector addition is indicative of the degree of collector-mineral interaction [28]. From Figure 7, in the absence of tetrathionates $\left(0 \mathrm{mg} / \mathrm{L}, \mathrm{S}_{4} \mathrm{O}_{6}{ }^{2-}\right)$ there is a $72 \mathrm{mV}$ drop in mixed potential. In the presence of $500 \mathrm{mg} / \mathrm{L}$ of tetrathionates, the mixed potential drop is similar to that observed in the absence of tetrathionates. Whilst at a tetrathionate concentration of $2000 \mathrm{mg} / \mathrm{L}$, the mixed potential drop is $30 \mathrm{mV}$. These results are indicative of strong collector-mineral interactions when SIBX is added to deionised water and the $500 \mathrm{mg} / \mathrm{L}$ tetrathionate solution. In the $2000 \mathrm{mg} / \mathrm{L}$ tetrathionate solution, there is less collector-mineral interaction alluding to the passivation of the mineral surface by the species in the solution. 


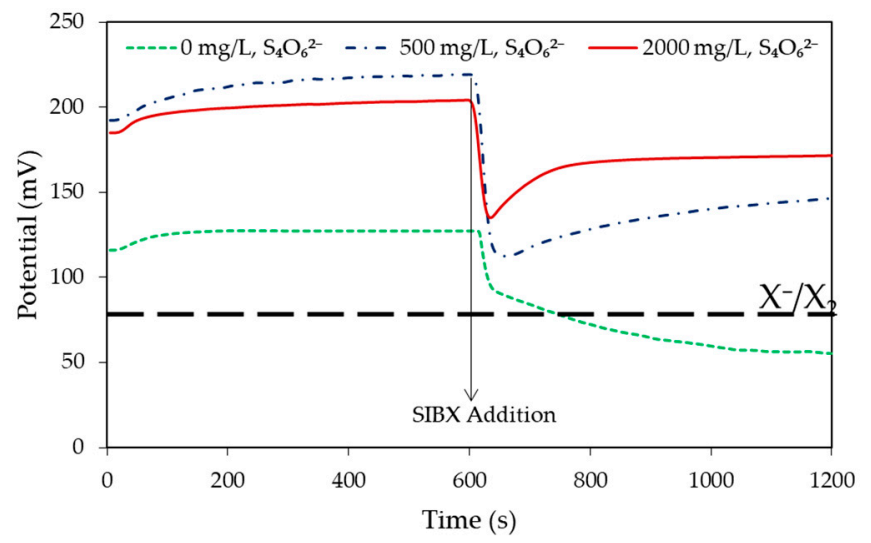

Figure 7. Mixed potential of galena in the presence of $2.4 \times 10^{-4} \mathrm{M} \mathrm{SIBX}, 0.1 \mathrm{M} \mathrm{Na}_{2} \mathrm{SO}_{4}$, and $0.05 \mathrm{M}$ $\mathrm{Na}_{2} \mathrm{~B}_{4} \mathrm{O}_{7}$ (pH 9.3) at $25^{\circ} \mathrm{C}, 500 \mathrm{mg} / \mathrm{L}$ tetrathionates, and $2000 \mathrm{mg} / \mathrm{L}$ tetrathionate solutions.

In agreement with previous literature, the equilibrium potential of galena in the absence of thiosalts exhibits a negative potential with respect to the dixanthogen couple $\left(\mathrm{X}^{-} / \mathrm{X}_{2}\right)$ [48]. For SIBX in neutral to slightly alkaline $\mathrm{pH}(\mathrm{pH} 7-9)$, the dixanthogen couple has been studied and the literature proposes a corrected potential of ca. $0.108 \mathrm{~V}$ as shown in Figures 7 and 8 [49,50]. Regarding interactions of sulphide minerals with a xanthate collector, positive equilibrium potentials with respect to the dixanthogen couple are indicative of dixanthogen species on the mineral surface whilst a metal thiolate is predicted to exist at a negative potential to the dixanthogen couple [28,48,49]. An interesting observation is the positive equilibrium potentials with respect to the dixanthogen couple alluding to equilibrium potentials in an oxidative environment suitable for dixanthogen generation on galena in the presence of tetrathionate ions. In this study tetrathionates, are potential determining by promoting an oxidizing environment in the system. It must, however, be recalled that dixanthogen was not observed on galena surfaces during FTIR studies. This inconsistency could be because the electrochemical cell environment is an ideal system and more sensitive and differs significantly from the conditioning environment used for FTIR studies.

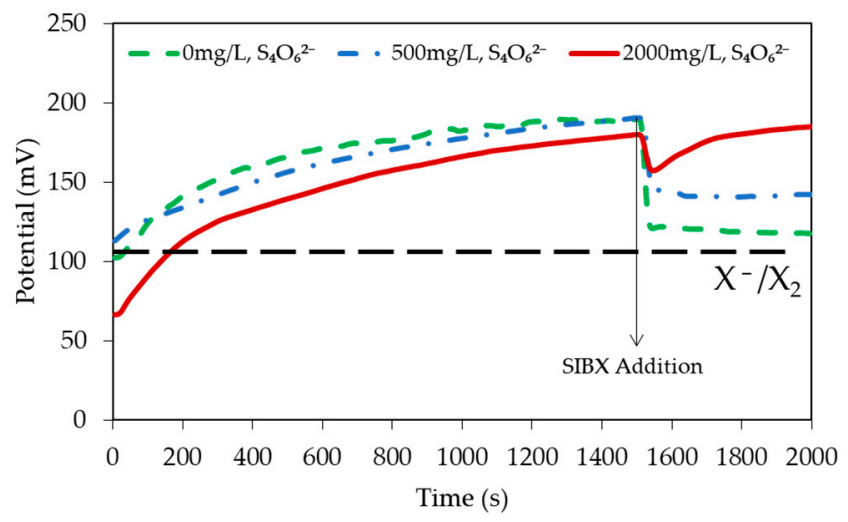

Figure 8. Mixed potential of chalcopyrite in the presence of $2.4 \times 10^{-4} \mathrm{M} \mathrm{SIBX}, 0.1 \mathrm{M} \mathrm{Na}_{2} \mathrm{SO}_{4}$, and $0.05 \mathrm{M} \mathrm{Na}_{2} \mathrm{~B}_{4} \mathrm{O}_{7}(\mathrm{pH} 9.3)$ at $25^{\circ} \mathrm{C}, 500 \mathrm{mg} / \mathrm{L}$ tetrathionates, and $2000 \mathrm{mg} / \mathrm{L}$ tetrathionate solutions.

\subsubsection{Chalcopyrite Rest Potential Measurements}

Figure 8 presents the rest potential measurements for chalcopyrite in different solution conditions. In deionised water, the rest potential drops by $70 \mathrm{mV}$ after interaction with SIBX. In the $500 \mathrm{mg} / \mathrm{L}$ tetrathionate solution, the chalcopyrite rest potential declines by $50 \mathrm{mV}$ whilst at $2000 \mathrm{mg} / \mathrm{L}$ there is minimal interaction as the potential slightly declines upon xanthate addition, however, recovering to its original value. The drop in potential followed by a subsequent increase in the potential to original potential values could be 
indicative of an initially chemisorbed but unstable xanthate species which was consumed from the mineral surface. In all conditions investigated, the equilibrium mixed potential was positive with respect to the xanthate/dixanthogen couple. It is therefore expected that dixanthogen must form on the mineral surfaces. Albeit the presence of dixanthogen on the chalcopyrite surface, chemisorbed xanthate which eventually converts to metal thiolate has been reported to exist on minerals such as chalcopyrite and pentlandite [28,51]. In separate studies, spectroscopic analysis of chalcopyrite has identified a metal thiolate layer co-adsorbed with dixanthogen on the mineral surface [52-54]. FTIR explored in the current study also identified dixanthogen and cuprous(I) butyl xanthate (CuBX) on the mineral surface.

The rest potential measurements on galena and chalcopyrite have revealed that at high tetrathionate concentrations, the collector-mineral interaction is significantly reduced. This result supports the FTIR studies and the hypothesis that, tetrathionates in high concentrations have the potential to render the mineral surface inactive due to the consumption of xanthate and subsequent formation of decomposition products and stable metal-thiosalt complexes that passivate sulphide mineral. The instability of metal-xanthate complexes and chemisorbed metal thiolate species increases in solutions where xanthate-thiosalt reaction products exist. This result shows that the chemisorption of xanthate is limited in the presence of high tetrathionate concentrations in accord with previously stated electrochemical observations.

\subsection{Microflotation Studies}

Mineral recovery was used as a measure of flotation performance in the different flotation conditions evaluated. Figure 9 shows the cumulative recovery of chalcopyrite and galena subjected to different conditions. The collectorless flotation in deionised water results in a chalcopyrite recovery of $70 \%$ and galena recovery of $45 \%$. After molybdenite, chalcopyrite has generally been accepted to be the most naturally floatable of the common sulphide minerals. The natural floatability of chalcopyrite, galena, and sulphide minerals in general is attributed to the presence of mildly oxidised species on a surface; elemental sulphur and sulphur-rich/metal deficient polysulphide species which may build up during grinding $[55,56]$. However, a heavily oxidised surface does not exhibit collectorless floatability $[17,21]$.

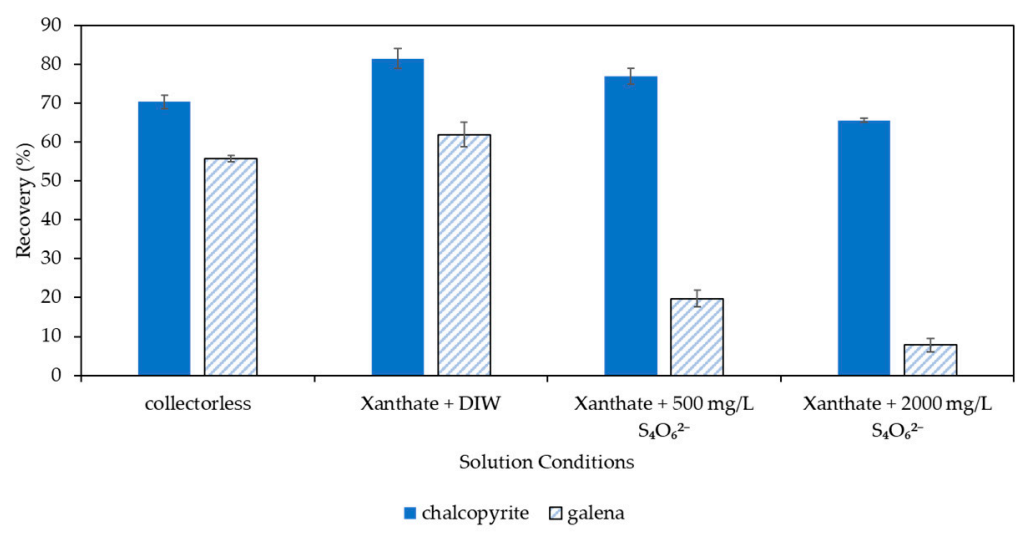

Figure 9. Galena and chalcopyrite cumulative recoveries at $\mathrm{pH} 8.5$ in the presence of a $50 \%$ pseudomonolayer SIBX coverage in the absence and presence of tetrathionate ions.

The addition of enough collector for a 50\% pseudo-monolayer mineral coverage resulted in chalcopyrite and galena recoveries of $80 \%$ and $60 \%$, respectively. The depressive effect of tetrathionates can be seen more evidently for galena. The galena recovery declined from $60 \%$ to $20 \%$ in the presence of $500 \mathrm{mg} / \mathrm{L}$ of tetrathionates and further declined to $8 \%$ in the presence of $2000 \mathrm{mg} / \mathrm{L}$ of tetrathionates. The reduction of tetrathionates in the presence of xanthate producing thiosulphates which adsorb on the mineral surface could 
explain the depression observed in this study. This observation supports findings made by Ozturk et al. [37]. The authors observed the significant depression galena in the $\mathrm{Cu}-\mathrm{Pb}$ flotation circuit in the flotation of a real complex ore after interaction of thiosulphate ions with the sulphide minerals. Studies by Patridge and Shimiizoka $[57,58]$ revealed galena depression seldomly occurs on clean galena, but heavily oxidised galena is depressed in the presence of sulphoxy compounds i.e., sulphite $\left(\mathrm{SO}_{3}{ }^{2-}\right)$ ions. This depression was attributed to the formation of a sparingly soluble lead sulphite film on the mineral surface which passivates the mineral surface. The depression of oxidised galena has been equally shown in the current study as elucidated by FTIR studies. Bulatovic [59], also reported that thiosulphate ions have the propensity to form complexes with metals that are more stable than the metal-xanthate complexes. Other literature also exists which proposes that the presence of thiosulphate and sulphate in solution is beneficial for collector adsorption through the generally accepted ion-exchange mechanism between the thiosalts and xanthate ions described by Alvarez and Wells $[12,60]$. The studies, however, made no mention of the extent of galena oxidation. There is a possibility that excess thiosalts in solution may begin to reduce the recovery gains of having thiosalts on the mineral surface as observed by the current study and that of Ozturk et al. [37].

As seen in Figure 9, chalcopyrite recovery was only affected by high tetrathionate concentrations. The mineral recovery declined from $81 \%$ to $77 \%$ when floated in a $500 \mathrm{mg} / \mathrm{L}$ tetrathionate solution which could be insignificant with the error range. On conditioning in $2000 \mathrm{mg} / \mathrm{L}$ tetrathionate solution, chalcopyrite recovery declined to $65 \%$. Due to the presence of thiosulphate and xanthyl thiosulphate in solution, the depression on the chalcopyrite surface could be due to the formation of a copper thiosulphate complex according to Equation (5), [14]:

$$
2 \mathrm{Cu}^{2+}+6 \mathrm{~S}_{2} \mathrm{O}_{3}{ }^{2-}=2\left[\mathrm{Cu}\left(\mathrm{S}_{2} \mathrm{O}_{3}\right) 2\right]^{3-}+\mathrm{S}_{4} \mathrm{O}_{6}{ }^{2-} .
$$

The current study has demonstrated how galena is more sensitive to the presence of tetrathionates confirming literature which showed that galena is more susceptible to depression by process water $[20,37]$. At low concentrations, galena and chalcopyrite depression may not be appreciated, however, as the sulphoxy ions begin to build up depression is appreciable even for the more floatable chalcopyrite. This phenomenon can have a significant bearing in $\mathrm{Cu}-\mathrm{Pb}$ separation in circuits using recycled water loaded with thiosalts or operations using sulphoxy compounds as depressants in the place of cyanide. The microflotation tests also support the FTIR studies and rest potential measurements which showed reduced collector-mineral interaction at high tetrathionate concentrations. It must be borne in mind that using single mineral allows the use of relatively pure minerals whilst minimising the effect of external influences such as purity, mineral associations, and liberation on flotation performance. On the plant, flotation recoveries may not be as high as seen in these microflotation tests, however these microflotation tests serve as a sound base for fundamental studies. To complement these pure mineral studies further work will be reported in which real ores will be tested in batch flotation studies.

\section{Conclusions}

This study has successfully shown that xanthate is degraded in the presence of tetrathionates with significant impacts on the flotation recovery of sulphide minerals. Tetrathionates produced due to the oxidative ore dissolution of sulphide minerals consume xanthate producing thiosulphates and xanthyl thiosulphates which are capable of forming complexes with metals that passivate sulphide minerals.

Microflotation tests have shown that chalcopyrite and galena are depressed at high concentrations of tetrathionates in solution ca. $2000 \mathrm{mg} / \mathrm{L}$. Galena is more sensitive to the presence of tetrathionates as it is depressed to a greater extent in comparison to chalcopyrite. At low concentrations ca. $500 \mathrm{mg} / \mathrm{L}$, chalcopyrite flotation recoveries are unaffected by tetrathionates in solution. It is common plant practice to assume that chalcopyrite is unaffected by the presence of sulphoxy species in solution. This study has equally shown 
the resilience of chalcopyrite in the presence of tetrathionates. The sensitivity of galena to tetrathionates may introduce recovery problems in $\mathrm{Cu}-\mathrm{Pb}-\mathrm{Zn}$ circuits where galena and chalcopyrite are often bulk floated to separate them from sphalerite and pyrite.

FTIR measurements and rest potential measurements successfully showed that collectormineral interactions decrease when minerals are subjected to conditioning in solutions with high tetrathionate concentrations. The formation of metal-thiosalt complexes on the mineral surface passivates the mineral. Besides thiosulphate forming on the mineral surface as a tetrathionate reduction product, it must be noted that there is a possibility of tetrathionate ions directly interacting with the mineral surface. The presence of tetrathionates and thiosulphates on sulphide minerals can prevent electron transfer across the mineral surface which acts as the semiconducting anodic site in the electrochemically driven adsorption of thiol collectors on sulphide minerals. Metal xanthates formed on the mineral surface are destabilised in the presence of tetrathionates. The poor flotation performance could therefore be attributed to mineral passivation by sulphoxy compounds and collector consumption in solution.

Massive sulphide processing plants that implement water recycling must bear in mind the influence of water quality of flotation performance. As water recycling contributes to the accumulation of thiosalts and polythionates in process water, reagent dosing regimens may need to be aggressive to counter depressive effects of thiosalts on valuable minerals. The current study is not exhaustive as other water quality parameters may be detrimental or beneficial to sulphide flotation. This study, however, lays a solid foundation upon which the importance of previously overlooked tetrathionates can be considered in water analysis and flotation circuit performance.

Supplementary Materials: The following are available online at https:/ / www.mdpi.com/2075-163 X/11/2/204/s1, Table S1: Original Data, Table S2: ANOVA: Two-Factor, Table S3: ANOVA Statistics.

Author Contributions: Conceptualisation, N.M., N.S. and K.C.; methodology, N.M., N.S., K.C. and L.P.; validation, N.M., N.S. and K.C.; formal analysis, N.M.; investigation, N.M.; resources, N.S. and K.C.; data curation, N.M.; writing-original draft preparation, N.M.; writing-review and editing, N.M., N.S. and K.C.; supervision, N.S. and K.C.; project administration, N.S.; funding acquisition, N.S. and K.C. All authors have read and agreed to the published version of the manuscript.

Funding: This research received funding from the European Union H2020 Programme under grant agreement no. 730480 funding.

Institutional Review Board Statement: Not applicable.

Informed Consent Statement: Not applicable.

Data Availability Statement: Not applicable.

Acknowledgments: The authors would like to acknowledge the Department of Bioproducts and Biosystems at Aalto University, Aalto University Bioeconomy Facilities and the Centre for Minerals Research (CMR) at the University of Cape Town for supporting this project. This work was also made possible by Heidi Meriö-Talvio and Özlem Bicak.

Conflicts of Interest: The authors declare no conflict of interest.

\section{References}

1. Zhang, H.; Jeffrey, M.I. A kinetic study of rearrangement and degradation reactions of tetrathionate and trithionate in near-neutral solutions. Inorg. Chem. 2010, 49, 10273-10282. [CrossRef]

2. Yong, X. Kinetics of Redox Transformation of Aqueous Sulpfur Species: The Role of Intermediate Sulfur Oxyanions and Mineral Surfaces; Sate University of New York: Stony Brook, NY, USA, 1997.

3. Peres, A.E.C. The Interaction between Xanthate and Sulphur Dioxide in the Flotation of Nickel-Copper Sulphide Ores. Ph.D. Thesis, The University of British Columbia, Vancouver, BC, Canada, 26 July 1979.

4. Schippers, A.; Jozsa, P.G.; Sand, W. Sulfur chemistry in bacterial leaching of pyrite. Appl. Environ. Microbiol. 1996, 62, 3424-3431. [CrossRef] [PubMed]

5. Bernier, L.; Warren, L.A. Geochemical diversity in S processes mediated by culture-adapted and environmental-enrichments of acidithiobacillus. Spp. Geochim. Cosmochim. Acta 2007, 71, 5684-5697. [CrossRef] 
6. Wentzien, S.; Sand, W.; Albertsen, A.; Steudel, R. Thiosulfate and tetrathionate degradation as well as biofilm generation by thiobacillus intermedius and thiobacillus versutus studied by microcalorimetry, HPLC, and ion-pair chromatography. Arch . Microbiol. 1994, 161, 116-125. [CrossRef]

7. Sorokin, D.Y.; Teske, A.; Robertson, L.A.; Kuenen, J.G. Anaerobic oxidation of thiosulfate to tetrathionate by obligately heterotrophic bacteria, belonging to the Pseudomonas Stutzeri Group. FEMS Microbiol. Ecol. 1999, 30, 113-123. [CrossRef] [PubMed]

8. Negeri, T.; Paktunc, A.; Boisclair, M.; Kingston, D. Characterization of Thiosalts Generation during Milling of Sulphide Ores; Mining and Mineral Sciences Laboratories Report MMSL 99-055 (CR); CANMET: Toronto, ON, Canada, October 1999.

9. Wasserlauf, M.; Dutrizac, J.E. Canmet's Project on the Chemistry, Generation and Treatment of Thiosalts in Milling Effluents. Can. Metall. Q. 1984, 23, 259-269. [CrossRef]

10. Rolia, E.; Tan, K.G. The Generation of Thiosalts in Mills Processing Complex Sulphide Ores. Can. Metall. Q. 1985, $24,293-302$. [CrossRef]

11. Leja, J. Surface Chemistry of Froth Flotation; Plenum Press: New York, NY, USA, 1982; pp. 401-412.

12. Wells, P.F.; Van Cleave, A.B. The Mechanism of the Adsorption of Ethyl Xanthate Ion on Galena (II). Can. J. Chem. Eng. 1975, 53, 641-646. [CrossRef]

13. Kirjavainen, V.; Schreithofer, N.; Heiskanen, K. Effect of calcium and thiosulfate ions on flotation selectivity of nickel-copper ores. Miner. Eng. 2002, 15, 1-5. [CrossRef]

14. Eliseev, N.I.; Kirbitova, N.V. Chalcopyrite and pyrite depression with a mixture of hyposulfite and copper sulfate. Sov. J. Non-Ferrous Met. 1984, 1, 125-126.

15. Petrus, H.T.B.M.; Hirajima, T.; Sasaki, K.; Okamoto, H. Effects of sodium thiosulphate on chalcopyrite and tennantite: An insight for alternative separation technique. Int. J. Miner. Process. 2012, 102-103, 116-123. [CrossRef]

16. Liu, Q.; Zhang, Y. Effect of Calcium Ions and Citric Acid on the Flotation Separation of Chalcopyrite from Galena Using Dextrin. Miner. Eng. 2000, 13, 1405-1416. [CrossRef]

17. Ralston, J. The chemistry of galena flotation: Principles \& practice. Miner. Eng. 1994, 7, 715-735.

18. Chen, J.M.; Liu, R.M.; Siu, W.; Qiu, G.Z. Effect of mineral processing wastewater on flotation of sulfide minerals. Trans. Nonferrous Met. Soc. China 2009, 19, 454-457. [CrossRef]

19. Rao, S.R.; Finch, J.A. A review of water re-use in flotation. Miner. Eng. 1989, 2, 65-85. [CrossRef]

20. Ikumapayi, F.; Makitalo, M.; Johansson, B.; Rao, K.H. Recycling of process water in sulphide flotation: Effect of calcium and sulphate ions on flotation of galena. Miner. Eng. 2012, 39, 77-88. [CrossRef]

21. Ralston, J. Eh and its consequences in sulphide mineral flotation. Miner. Eng. 1991, 4, 859-878. [CrossRef]

22. Taguta, J.; O'Connor, C.T.; McFadzean, B. The effect of the alkyl chain length and ligand type of thiol collectors on the heat of adsorption and floatability of sulphide minerals. Miner. Eng. 2017, 110, 145-152. [CrossRef]

23. Grano, S.R.; Prestidge, C.A.; Ralston, J. Solution interaction of ethyl xanthate and sulphite and its effect on galena flotation and xanthate adsorption. Int. J. Miner. Process. 1997, 52, 161-186. [CrossRef]

24. Silverstein, T.P. Nonlinear and linear regression applied to concentration versus time kinetic data from Pinhass Sanitizer Evaporation Project. J. Chem. Educ. 2011, 88, 1589-1590. [CrossRef]

25. Le, T.M.K.; Schreithofer, N.; Dahl, O. Dissolution Test protocol for estimating water quality changes in minerals processing plants operating with closed water circulation. Minerals 2020, 10, 653. [CrossRef]

26. Miranda-Trevino, J.C.; Pappoe, M.; Hawboldt, K.; Bottaro, C. The importance of thiosalts speciation: Review of analytical methods, kinetics, and treatment. Crit. Rev. Environ. Sci. Technol. 2013, 43, 2013-2070. [CrossRef]

27. O'Reilly, J.W.; Dicinoski, G.W.; Miura, Y.; Haddad, P.R. Separation of thiosulfate and the polythionates in gold thiosulfate leach solutions by capillary electrophoresis. Electrophoresis 2003, 24, 2228-2234. [CrossRef]

28. Tadie, M.; Corin, K.C.; Wiese, J.G.; O'Connor, C.T. Electrochemical interactions of platinum group minerals with copper sulphate. Miner. Eng. 2017, 112, 43-49. [CrossRef]

29. Bradshaw, D.J.; Connor, C.T. Measurement of the sub-process of bubble loadin in flotation. Miner. Eng. 1996, 9, 443-448. [CrossRef]

30. Shen, Y.; Nagaraj, D.R.; Farinato, R.; Somasundaran, P. Study of xanthate decomposition in aqueous solutions. Miner. Eng. 2016, 93, 10-15. [CrossRef]

31. Mhonde, N.; Schreithofer, N.; Corin, K.C.; Mäkelä, M. Assessing the Combined Effect of Water Temperature and Complex Water Matrices on Xanthate Adsorption Using Multiple Linear Regression. Minerals 2020, 10, 553. [CrossRef]

32. Grano, S.R.; Johnson, N.W.; Ralston, J. Control of the solution interaction of metabisulphite and ethyl xanthate in the flotation of the hilton ore of Mount Isa Mines Limited, Australia. Miner. Eng. 1997, 10, 17-39. [CrossRef]

33. Yamamoto, T. Mechanisms of Pyrite Depression by Sulphite in the Presence of Sphalerite. In Complex Sulphide Ores; Jones, M.H., Ed.; Institution of Mining and Metallurgy: London, UK, 1981; pp. 71-78.

34. Jones, M.H.; Woodcock, J.T. Formation and recognition of alkyl xanthyl thiosulphates in sulphide ore flotation liquors. Int. J. Miner. Process. 1981, 8, 125-145. [CrossRef]

35. Misra, M.; Miller, J.; Song, Q. The Effect of $\mathrm{SO}_{2}$ in the Flotation of Sphalerite and Chalcopyrite. In Flotation of Sulphide Minerals; Forssberg, E., Ed.; Elsevier: Amsterdam, The Netherlands, 1985; pp. 175-196. 
36. Jones, M.H.; Woodcock, J.T. Ultraviolet Spectrometry of Flotation Reagents with Special Reference to the Determination of Xanthate in Flotation Liquors; Institution of Mining and Metallurgy: London, UK, 1973; pp. 1-25.

37. Öztürk, Y.; Bıçak, Ö.; Özdemir, E.; Ekmekçi, Z. Mitigation Negative Effects of Thiosulfate on Flotation Performance of a Cu-Pb-Zn Sulfide Ore. Miner. Eng. 2018, 122, 142-147. [CrossRef]

38. Cambron, A.; Whitby, G.S. The Oxidation of Xanthates and Some New Dialkyl Sulphur- and Disulphur- Dicarbothionates. Can. J. Res. 1930, 2, 144-154. [CrossRef]

39. Pappoe, M. Applications of Capillary Electrophoresis and Mass Spectometry for the Analysis of Thiosalts. Ph.D. Thesis, Memorial University of Newfoundland, St. John's, NL, Canada, November 2014.

40. Goldhaber, M.B. Experimental study of metastable sulfur oxyanion formation during pyrite oxidation at PH 6-9 and $30{ }^{\circ} \mathrm{C}$. Am. J. Sci. 1983, 283, 193-217. [CrossRef]

41. De Donato, P.; Cases, J.M.; Kongolo, M.; Michot, L.; Burneau, A. infrared investigation of amylxanthate adsorption on Galena: Influence of oxidation, PH and grinding. Colloids Surf. 1990, 44, 207-228. [CrossRef]

42. Cases, J.M.; De Donato, P. FTIR analysis of sulphide mineral surfaces before and after collection: Galena. Int. J. Miner. Process. 1991, 33, 49-65. [CrossRef]

43. Persson, I.; Persson, P.; Valli, M.; Fözö, S.; Malmensten, B. Reactions on sulfide mineral surfaces in connection with xanthate flotation studied by diffuse reflectance FTIR spectroscopy, atomic absorption spectrophotometry and calorimetry. Int. J. Miner. Process. 1991, 33, 67-81. [CrossRef]

44. Zhang, Y.; Cao, Z.; Cao, Y.; Sun, C. FTIR studies of xanthate adsorption on chalcopyrite, pentlandite and pyrite surfaces. J. Mol. Struct. 2013, 1048, 434-440. [CrossRef]

45. Leppinen, J.O. FTIR and flotation investigation of the adsorption of ethyl xanthate on activated and non-activated sulfide minerals. Int. J. Miner. Process. 1990, 30, 245-263. [CrossRef]

46. Mielczarski, J.A.; Mielczarski, E.; Cases, J.M. Influence of chain length on adsorption of xanthates on chalcopyrite. Int. J. Miner. Process. 1998, 52, 215-231. [CrossRef]

47. Li, Y.; Li, W.; Wei, Z.; Xiao, Q.; Lartey, C.; Li, Y.; Song, S. The influence of common chlorides on the adsorption of SBX on chalcopyrite surface during flotation process. Miner. Process. Extr. Metall. Rev. 2019, 40, 129-140. [CrossRef]

48. Allison, S.A.; Goold, L.A.; Nicol, M.J.; Granville, A. Determination of the products of reaction between various sulfide minerals and aqueous xanthate solution, and a correlation of the products with electrode rest potentials. Met. Trans. 1972, 3, $2613-2618$. [CrossRef]

49. Buswell, A.M.; Bradshaw, D.J.; Harris, P.J.; Ekmekci, Z. The use of electrochemical measurements in the flotation of a platinum group minerals (PGM) bearing ore. Miner. Eng. 2002, 15, 395-404. [CrossRef]

50. Winter, G.; Woods, R. The relation of collector redox potential to flotation efficiency: Monothiocarbonates. Sep. Sci. Technol. 1973, 8, 261-267. [CrossRef]

51. Hodgson, M.; Agar, G.E. Electrochemical investigations into the flotation chemistry of pentlandite and pyrrhotite: Process water and xanthate interactions. Can. Metall. Q. 1989, 28, 189-198. [CrossRef]

52. Fuerstenau, M.C.; Chander, S.; Woods, R. Froth Flotation. In Froth Flotation: A Century of Innovation; Fuerstenau, M.C., Jameson, G., Yoon, R., Eds.; Society for Mining, Metallurgy and Exploration: Littleton, CO, USA, 2007.

53. Bowden, J.L.; Young, C.A. Xanthate chemisorption at copper and chalcopyrite surfaces. J. South. African Inst. Min. Metall. 2016, 116, 503-508. [CrossRef]

54. Mielczarski, J.A.; Mielczarski, E.; Cases, J.M. Interaction of Amyl xanthate with chalcopyrite, tetrahedrite, and tennantite at controlled potentials. simulation and spectroelectrochemical results for two-component adsorption layers. Langmuir 1996, 12, 6521-6529. [CrossRef]

55. Buckley, A.N.; Hamilton, I.C.; Woods, R. Investigation of the surface oxidation of sulphide minerals by linear potential sweep and X-ray photoelectron. In Flotation of Sulphide Minerals; Forssberg, K.S.E., Ed.; Elsevier: Amsterdam, The Netherlands, 1985; pp. $41-60$.

56. Hu, Y.; Sun, W.; Wang, D. (Eds.) Electrochemistry of Flotation of Sulphide Minerals; Tsinghua University Press: Beijing, China, 2009.

57. Shimoiizaka, J.; Usui, S.; Matsuoka, I.; Sasaki, H. Depression of Galena Flotation by Sulfite or Chromate Ion. In Flotation; Gaudin, A., Fuerstenau, M.C., Eds.; Australasian Institute of Mining, Metallurgy and Petroleum Engineers, Inc.: Baltimore, MD, USA, 1976; Volume 1, pp. 393-412.

58. Pattison, I. The Action of Sodium Sulphite as a Depressant in Sulphide Mineral Flotation Systems Containing Chalcopyrite, Galena, Pyrite and Sphalerite. Ph.D. Thesis, The University of Melbourne, Melbourne, Australia, October 1981.

59. Bulatovic, S.M. Flotation of Sulfide Ores, Handbook of Flotation Reagents: Chemistry, Theory and Practice; Elsevier: Amsterdam, The Netherlands, 2007. [CrossRef]

60. Elizondo-Álvarez, M.A.; Dávila-Pulido, G.I.; Bello-Teodoro, S.; Uribe-Salas, A. Role of PH on the adsorption of xanthate and dithiophosphinate onto Galena. Can. Metall. Q. 2019, 58, 107-115. [CrossRef] 